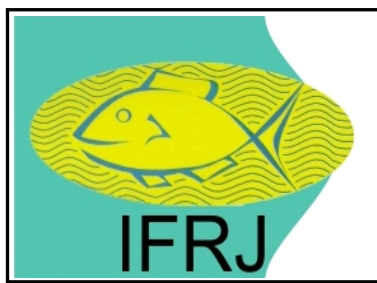

Available online at: http://ejournal-balitbang.kkp.go.id/index.php/ifrj

e-mail:ifrj.puslitbangkan@gmail.com

INDONESIAN FISHERIES RESEARCH JOURNAL

Volume 22 Number 1 June 2016

p-ISSN: 0853-8980

e-ISSN: 2502-6569

Accreditation Number: 704/AU3/P2MI-LIPI/10/2015

\title{
CURRENT STATUS OF THE POLE-AND-LINE FISHERY IN EASTERN PART OF INDONESIA
}

\author{
Agustinus Anung Widodo*1, Wudianto' ${ }^{1}$ and Fayakun Satria ${ }^{2}$ \\ ${ }^{1)}$ Research Center for Fisheries Management and Conservation, Jl. Pasir Putih II Ancol Timur-Jakarta-14430 \\ 2) Research Institute for Fish Enchancement and Conservation, Jl. Muara Baru Ujung, Jakarta-14430 \\ Received; January 06-2016 Received in revised from June 08-2016; Accepted June 13-2016
}

\begin{abstract}
The promotion of pole-and-line fishery for a selective gear operating in the Indonesian tuna management area is considered as the proper policy in response to the increasing market demand with tuna eco-labeled. Appropriate information in addressing the current status of the pole-and-line fishery in Indonesia is an important step in order to support the promotion. Data used to describe the fishery were obtained through scientific port sampling program in collaboration between RCFMC and WCPFC in 2010 to 2014 and also scientific observer onboard program collaboration RCFMC and CRAC Co. Ltd. in 2013. The results show that presently the number of pole and line fleets was decreased significantly and remain about 232 fleetsin Sorong, Bitung and Kendari and Larantuka. The national annual total catch of pole-and line during $1980-$ 2013 was recorded between 24,000 and 160,000 tons per year (average 98,117 tons per year). This value is estimated to contribute about $20 \%$ of Indonesia annual total catch of tuna in FMAs713-717. The pole-andline catch rates based at Bitung, Kendari and Sorong were fluctuated in each year with the range respective between 8.79 and 17.93 tons/trip/vessel, 4.78 and 5.36 ton/trip/vessel and about 7,99 ton ton/trip/vessel. Pole-and-line fishery operated in Indonesian FMAs 713-717 is considered as selective fishery, with > $80 \%$ catches of skipjack in matured stage. The tuna-live bait fish ratio in Indonesian pole-and-line was $4.41: 1$, then an improvement of live bait ratio as well as its management is required.
\end{abstract}

Keywords: Current status; pole and line; Indonesia

\section{INTRODUCTION}

Pole-and-line that locally known as huhate has been used as a fishing gearby Indonesian fishers since long time ago to capture mainly skipjack (Katsuwonus pelamis). The pole-and-line fishery has been developed mainly in the eastern part of Indonesia particularly in the water northern off Papua, Sulawesi and Maluku. Fishing operation of pole-and-line is mainly in within five out of eleven Indonesian Fisheries Management Areas or FMA that are FMA 713, 714, 715,716 and 717.

The pole-and-line fishing method is involving two interlinked fisheries both live bait fisheries and tuna fisheries. Live bait fisheries is supporting the poleand-line fishing operation in targeting skipjack. The sustainability and availability of live bait for pole-and-line operation is essential for this fishery. To date Indonesia does not havea specific management measure ensuring long-term sustainability of live bait resources.
Pole-and-line fishers operate their gear either within free fish schooling or around drifting log or flotsam. They are also fishing in the around of seamounts to target the free schooling of skipjack. The Indonesian pole-and-line fishers are mostly using fish aggregating devices (FADs) in their fishing. The use of FAD inpoleand-line fishery are mainly to attract fish school but at the same time during the fishing operation is still utilized live-bait to manipulate line hook with the live bait and catch the skipjack schooling While targeting skipjack, the pole-and-line fishing operation also catch small number of juvenile yellowfin tuna (Thunnus albacares), bigeye tuna (Thunnus obesus) and neritic tuna as by catch.

The tuna resources in FMAs 713 to 717 are not only caught by pole and line but also other gears such as purse seine, tuna long line, hand line and troll line. In 2015, Directorate General of Capturte Fisheries (DGCF)-Ministry of Marine Affairs and Fisheries (MMAF) Republic of Indonesia has registered about 398 tuna vessels to the Western and Central Pacific 
Fisheries Commission-WCPFC https://www.wcpfc. int/ record-fishing-vessel-database) consisted of 26 pole-and-liners, 160 tuna long liners, 124 purse seines, 1 gillnetters, 4 hand liners, 26 fish carriers, 55 support vessels, 2 not specified fishing vessels. Due to the result of there having been Ministry of Marine Affairs and Fisheries regulations particularly Ministerial Decree No. 56 year 2014 about moratorium fishing business licensing in Indonesia FMA, it is predicted that the number of each fleet is far below the actual number. The vessel owner has officially registered their fleets to the RFMOs through the Indonesian government (DGCF) due to the requirement by the market, butitis not the case for most vessels selling domestically their catch.

Most of the pole-and-line catch from Indonesia is locally marketed (Gillett, 2011). While there is also a growing demand from tuna fish processing industries to only accept an eco-labeling and eco-certified fishing product which a pole and line fisheries has a better position compare to purse seiner. For example, the UK canned tuna market has a very effective public campaign promoting a shifting to pole-and-line product and this also followed by the US market (Gillett, 2010). It is predicted that the demand of pole-and-line product will increase in the near future. Indonesia needs to consider seriously improving and developing the management of pole-and-line fisheries to anticipate the market demand. This paper describes the current status of the pole-and-line fishery in Indonesia.

\section{MATERIALS AND METHODS}

Primary data were obtained from research collaboration between Research Center for Fisheries Management and Conservation or RCFMC and Western and Central Pacific Fisheries Commission or WCPFCthrough port sampling program between 2010 and 2014. Primary data were also obtained from research collaboration RCFMC and Citra Raja Ampat Canning or CRAC Co. Ltd through onboard observer program in 2013.CRAC Co Ltd is a fishery company based in Sorong-West Papua which operates poleand-line fleet. The main fishing ground of CRAC Co Ltd.'s pole-and-line fleets are Indonesian FMA 717.

Data of pole-and-line fishery recorded from port sampling program included: fishing ground or estimation of FADs position obtained from skipper, effort includes number fishing day, estimation number of live-bait fish used in bucket, number of fisher or crew, catch includes total catch in $\mathrm{kg}$ or ton, composition of catch by species, and catch size in fork-length. Data recorded from on board observer program included effort in number of effective fishing days, number live-bait fish used in buckets, species of live-bait used, number and position of FADs visited, number of free schooling which is fished, catch includes number but regardless of species. Observer program was also recorded the data of periods or time when the pole-and-lines were not fished. The reasons pole-and-liner is not fishing include bad weather, steaming to and from the fishing grounds, preparing for fishing, time spent in handling the catch and no bait available.

Secondary data were obtained from Bitung Oceanic Fishing Port, Kendari Oceanic Fishing Port, Citra Raja Ampat Canning Co. Ltd. Located in Sorong. The data included number of vessel landing, vessel specification, and monthly catch of pole-and-line fleet. The catch rate or catch ability is calculated using equation as presented by Petrere et al.(2010) as below:

$$
\text { CPUE }=\frac{\sum C i}{\sum f i}=\frac{\bar{C}}{-\bar{f}}
$$

where, $C_{i}$ is $i^{\text {th }}$ catch (ton), $f_{i}$ is its respective fishing effort (effective day of fishing).

\section{RESULTS AND DISCUSSION Results}

\section{Fleet}

The fleets were noted by referring to Indonesian Pole-and-line and Hand Line Fisheries Association or Asosiasi Perikanan Pole-and-line dan Handline Indonesia or AP2HI, in the absent of official data from DGCF. In 2015, AP2HI noted the active number of pole-and-line fleet in Sorong, Bitung and Kendari are 132 units. The number pole-and-line in Sorongis 34 unitswith size ranged $49-98 \mathrm{GT}$. The number poleand-line inBitungis 62unitswith size ranged 20-143 GT, and in Kendari, the number in 36 unitswith size ranged 14-34 GT. Gillet (2014) reported thatabout 80 to 100 pole-and-line vessels are based in Larantuka, but only about $60 \%$ are operationally active. Pole-and-line fleet structure of Sorong, Bitung and Kendari is presented in Figure 1. The Average crew of pole-and-line based in Sorong, Bitung and Kendari were 25 fishers, 30 fishers and 22 fishers respectively. 


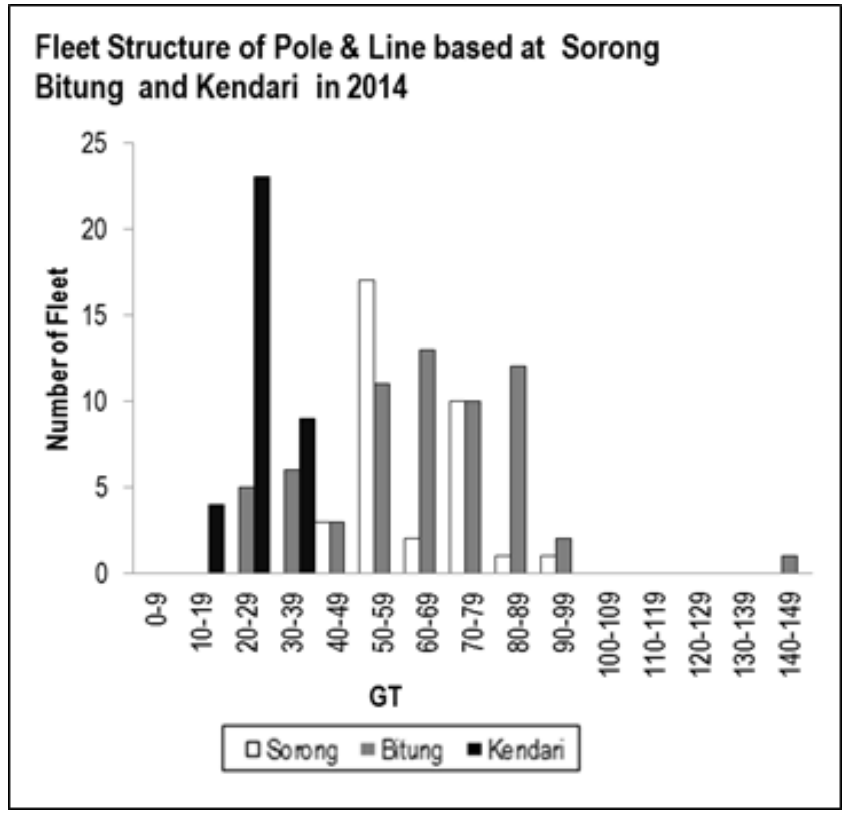

Figure 1. Fleet structure of pole-and-line based at Sorong, Bitung and Kendari in 2014.

\section{Fishing Ground}

The fishing ground of pole-and-line fishery is indicated by location the fishers deploy the Fish Aggregating Devices or FADs. Pole-and-line fishers have rarely fished in free schooling fish recently. They are highly dependent on FADs as a factor of success in the fishing practice. Inaccuracy of number and position of FADs in the fishing ground are the outstanding issue facing by fisheries manager. Achieving an estimate of the total number and position of FADs in the fishing ground proved difficult. This was largely the result of the current lack of effective systems of FAD registration and monitoring, and also because of the desire of fishing companies and vessel skippers to keep FADs position information confidential. Although current fisheries laws require the registration of FADs and owners of FADs to supply positional and vesseluse information for each FAD installed to Directorate General of Capture Fisheries in Jakarta. These laws have not yet been effectively implemented and adhered to. In general, National, Provincial, Regency and District offices of Ministry of Marine Affairs and Fisheries (MMAF) were unable to provide information of numbers and locations of FADs.

The positions of FADs that are presented in Figure 2 were obtained from enumerator program in Kendari, Bitung and Sorong as well as observer program in Sorong. The FADs position present in Figure 2 are not only for pole-and-line but include of purse seine and hand line/troll line fisheries as well.

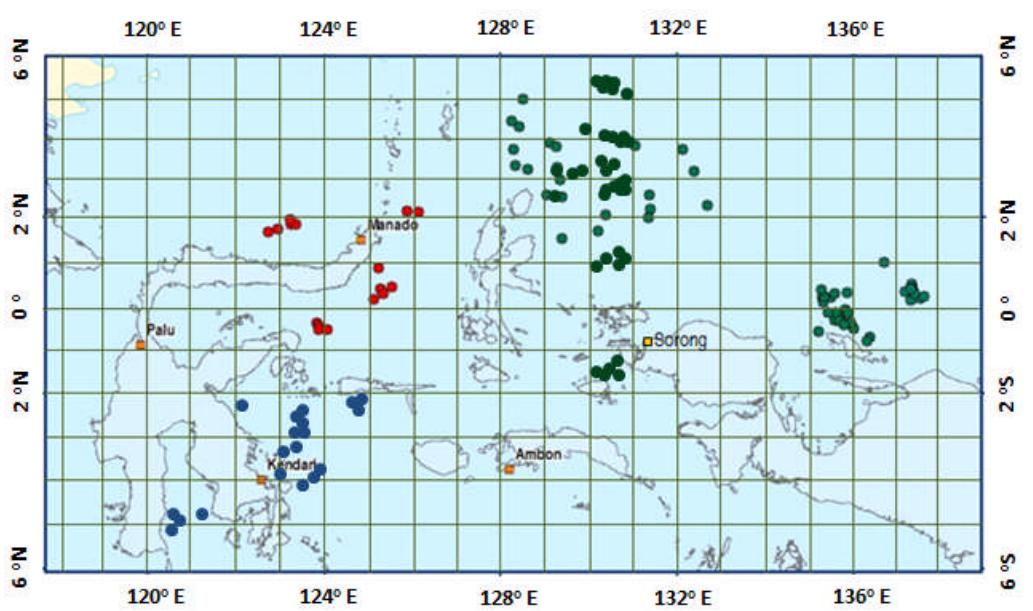

Figure 2. The FADs position which indicate as pole-and-line fishing ground. 


\section{Live-Baitfish}

The pole-and-line uses live-bait which is combined with water sprayed in the fishing to attract tuna and catch them. The live-baitfish is captured in a separate fishing operation using lift net gear or bagan. Bagan operates in the inshore waters and indicate as livebait fishing ground. Pole-and-line fleets based at Sorong obtained live bait from bagans operate in Misol, Kabui and Aljui. The other potensial bait fishing ground of pole-and line based Sorong are Fofak bay, Makebon, Redekorido, Rumberpon dan Ansoes bay.
Pole-and-line based at Bitung obtained live fish bait from bagans operate in Batu Putih Beach, Rondor Beach, Magogimbun bay and Matabulu waters. While pole-and-line based at Kendari obtained the livebaitfish from bagans operate in around of Umbele Island.Resul of observation show that at least 15 species of baitfish identified during observer program in Sorong as presented in Table1. The common species of live-baitfish used by pole-and-line based at Sorong. Live bait fish composition dominated by gold anchovy was $34.1 \%$ of seven buckets (about $35 \mathrm{~kg}$ ) samples.

Table 1. Live bait composition caught by bagan in vicinity of Misol, Kajui and Aljui waters-Sorong-West Papua during observer program in 2013.

\begin{tabular}{lllr}
\hline Local Name & Indonesia Name & Common Name & Composition (\%) \\
\hline PuriMerah & Teri & Gold anchovy & 34.1 \\
Puriputih & Teri & Blue anchovy & 17.2 \\
Purihitam & Teri & Oceanic anchovy & 10.6 \\
Lompe & Lompa & Little priest & 7.6 \\
Maeroa & Kasan & Little sprat & 6.7 \\
Gosao & Kasan & Blue sprat & 5.8 \\
Tendipang & Tembang & Sardine & 4.1 \\
Make & Tembang & Sardine & 3.2 \\
Sardin & Sardin & Sardine & 2.4 \\
Lolosimerah & Pisang-pisang & Fusilier & 2.0 \\
Lolosi & Pisang-pisang & Fusilier & 1.8 \\
Lolot (Sangsa) & Kembung & White lined & 1.3 \\
Momar (Malalugis) & Layang & Round scad & 1.1 \\
Tude & Bentong & Big-eye scad & 1.1 \\
Suntung & Cumi-cumi & Squid & 1.0 \\
\hline
\end{tabular}

The amount of tuna captured divided by the amount of bait used is known as tuna-baitfish ratio. Result of study in Sorong in 2013 shows that the average of baitfish used per trip per vessel was about 568 buckets or about 2.84 ton baitfish, one bucket contains about $5 \mathrm{~kg}$ baitfish. Total trip of 31 active pole-and-liners based at Sorong in 2013 was about 262, and the total of bait fish about 744.1 ton per year. The total catch of pole-and-line was about 3,285 ton tuna in 2013, so that tuna-baitfish ratio was 4.41:1.

\section{Catch Rate}

Result of port sampling program by enumerator in the three landing bases i.e.Bitung, Kendari and Sorong are presented in Table 2, indicating that catch rate of pole-and-line based at Bitung is fluctuated in each year between 8.79 ton/trip/vessel and 17.93 ton/ trip/vessel. The catch rate pole-and-line based at Kendariwasrelatively stable i.e. 4.78 ton/trip/vessel and 5.36 ton/trip/vessel. Catch rate pole-and-line from Sorong was onlyone year i.e. 7.99 ton ton/trip/vessel (Table 2). The average of the effecive day of pole-andline vessel based at Sorong, Bitung and Kendari were about 8,10 and 6 days per trip, respectively. The effective day is defined as the day when the pole-and line vesselis fishing. 
Table 2. Catch rate of pole-and-line based at Bitung, Kendari and Sorong in 2010-2014.

\begin{tabular}{|c|c|c|c|c|c|c|c|c|}
\hline \multirow{2}{*}{ Year } & \multirow{2}{*}{$\begin{array}{l}\text { Landing } \\
\text { Places }\end{array}$} & \multirow{2}{*}{$\begin{array}{l}\text { Fishing } \\
\text { Gear }\end{array}$} & \multirow{2}{*}{$\begin{array}{l}\text { Number } \\
\text { of Trip }\end{array}$} & \multicolumn{4}{|c|}{ Catch (TON) } & \multirow{2}{*}{$\begin{array}{l}\text { Catch Rate } \\
\text { (ton/trip/vessel) }\end{array}$} \\
\hline & & & & SKJ & YFT & BET & Total & \\
\hline \multirow[t]{2}{*}{2010} & Bitung & $\mathrm{PL}$ & 125 & $1,046.7$ & 19.6 & 28.7 & & 8.76 \\
\hline & Kendari & PL & 492 & 2.103 .2 & 238.6 & 0.0 & $\begin{array}{l}1,095.0 \\
2341.8\end{array}$ & 4.76 \\
\hline \multirow[t]{2}{*}{2011} & Bitung & $\mathrm{PL}$ & $\begin{array}{r}92 \\
92\end{array}$ & 523.1 & 0.0 & 10.3 & 533.4 & 5.80 \\
\hline & Kendari & PL & 469 & $1,613.9$ & 565.2 & 41.7 & $2,220.8$ & 4.74 \\
\hline \multirow[t]{2}{*}{2012} & Bitung & $\mathrm{PL}$ & 75 & $1,125.4$ & 0.0 & 96.6 & $1,322.0$ & 17.63 \\
\hline & Kendari & $\mathrm{PL}$ & 212 & 949.9 & 34.6 & 0.0 & 985.5 & 4.64 \\
\hline \multirow[t]{2}{*}{2013} & Bitung & $\mathrm{PL}$ & 218 & $3,046.3$ & 317.7 & 83.5 & $3,465.7$ & 15.81 \\
\hline & Kendari & $P L$ & 229 & 685.9 & 0.0 & 0.0 & 685.9 & 3.00 \\
\hline \multirow[t]{3}{*}{2014} & Bitung & $\mathrm{PL}$ & 173 & $2,117.8$ & 172.1 & 47.5 & $2,537.4$ & 14.67 \\
\hline & Kendari & $\mathrm{PL}$ & 98 & 370.5 & 118.6 & 0.0 & 489.1 & 4.99 \\
\hline & Sorong & $P L$ & 68 & 414.5 & 112.7 & 10.5 & 543.1 & 7.91 \\
\hline
\end{tabular}

Commercial pole-and-line fishing has begun to operate in the area of Eastern Indonesia when Indonesian government established some Government pole-and-line companies such as Usaha Mina and Perikani in early 1970s. Usaha Mina Company based at Sorong-Papua and Perikani Company based at Ambon-Maluku and also Bitung-North Sulawesi. Since the last 15 years the government pole-and-line companies were no longer operating and since then started developing private pole-and-line companies. There are about 15 fisheries private companies that operate pole-and-line in the area. The catch estimate of pole-and-line operated in Indonesian FMAs 713, $714,715,716$ and 717 is based on the result of national tuna catch estimate in2014 lead by DGCFMMAF (Figure 4). The catch of pole-and line during 1980 - 2013 was fluctuated between 24,000 and 160,000 ton per year with average 98,117 ton per year.

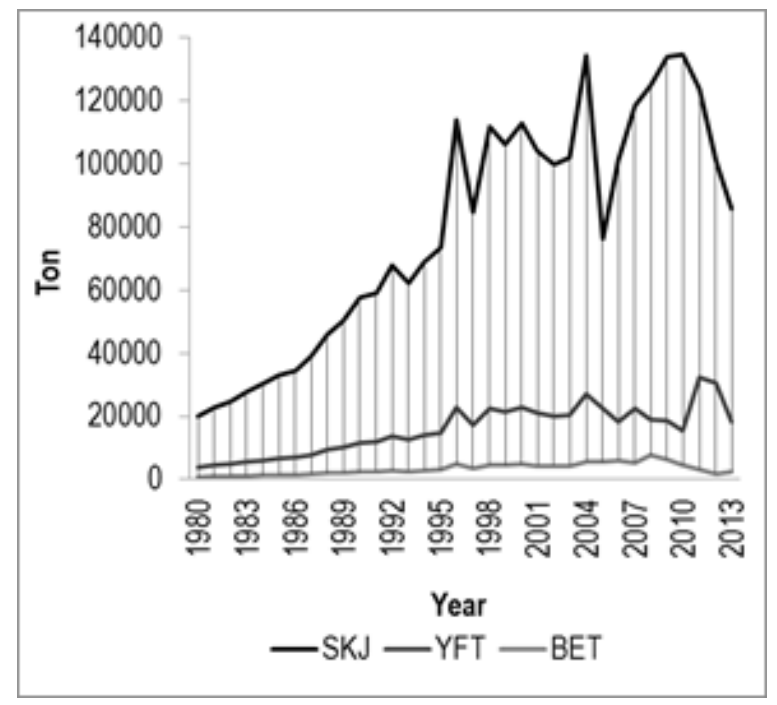

Figure 4. The estimate of total catch of pole-and-line operated in Indonesian FMAs713-717. Note: SKJ=skipjack tuna, YFT= yellowfin tuna, BET bigeye tuna

\section{Catch Composition}

Target of pole-and-line is skipjack tuna (Katsuwonuspelamis) with by-catch of yellowfin tuna (Thunnusalbacares) and bigeye tuna (Thunnusobesus) in juvenile stage and few of neritic tuna as well as sheer fish includes. Neritic tunas caugth by pole-and-line include frigate tuna (Auxist hazard), bullet tuna (Auxis rochei), kawa-kawa (Euthynnus affinis) and longtail tuna (Thunnus tonggol). Results of port sampling program in Sorong, Bitung and Kendari showsthat composition of skipjack tuna was about $77.1-92.7$ $\%$ of the total catch of tuna with average $77.8 \%, 83.7$ $\%$ and $80.7 \%$ in, in Sorong and Kendari, respectively (Tables 3, 4 and 5). 
Ind.Fish.Res.J. Vol.22 No.1 June 2016: 43-52

Table 3. The catch composition of pole-and-line based at Sorong

\begin{tabular}{cccc}
\hline \multirow{2}{*}{ Year } & \multicolumn{3}{c}{ Catch composition (\%) } \\
\cline { 2 - 4 } & Skipjack tuna & Yellowfin tuna & Bigeye tuna \\
\hline 2012 & 77.1 & 16.5 & 6.4 \\
2013 & 78.4 & 19.7 & 1.9 \\
Average & 77.8 & 13.0 & 4.2 \\
\hline
\end{tabular}

Table 4. The catch composition of pole-and-line based at Bitung

\begin{tabular}{cccc}
\hline \multirow{2}{*}{ Year } & \multicolumn{3}{c}{ Catch composition(\%) } \\
\cline { 2 - 4 } & Skipjack tuna & Yellowfin tuna & Bigeye tuna \\
\hline 2007 & 81.0 & 15.4 & 3.6 \\
2008 & 82.5 & 12.4 & 5.0 \\
2009 & 87.0 & 10.0 & 3.0 \\
2010 & 87.0 & 10.0 & 3.0 \\
2011 & 77.3 & 20.4 & 2.3 \\
2012 & 92.7 & 3.3 & 4.0 \\
2013 & 78.3 & 19.9 & 1.8 \\
\hline Average & 83.7 & 13.1 & 3.2 \\
\hline
\end{tabular}

Table 5. The catch composition of pole-and-line based at Kendari.

\begin{tabular}{lccc}
\hline \multirow{2}{*}{ Year } & \multicolumn{3}{c}{ Catch composition (\%) } \\
\cline { 2 - 4 } & Skipjack tuna & Yellowfin tuna & Bigeye tuna \\
\hline 2007 & 81.0 & 15.4 & 3.6 \\
2008 & 82.5 & 12.4 & 5.0 \\
2009 & 87.0 & 10.0 & 3.0 \\
2010 & 87.0 & 9.9 & 3.1 \\
2011 & 77.0 & 20.0 & 2.0 \\
2012 & 68.8 & 30.9 & 0.3 \\
2013 & 80.9 & 16.5 & 2.6 \\
\hline Average & 80.7 & 16.4 & 2.9 \\
\hline
\end{tabular}

\section{Catch size}

The size (fork length, FL) of sample of skipjack tuna caught usingpole-and-line at port sampling based at Sorong in 2013 ranged between $25-70 \mathrm{~cm}$, with highest modus of $56-58 \mathrm{~cm}$ in April (Figure 5). 

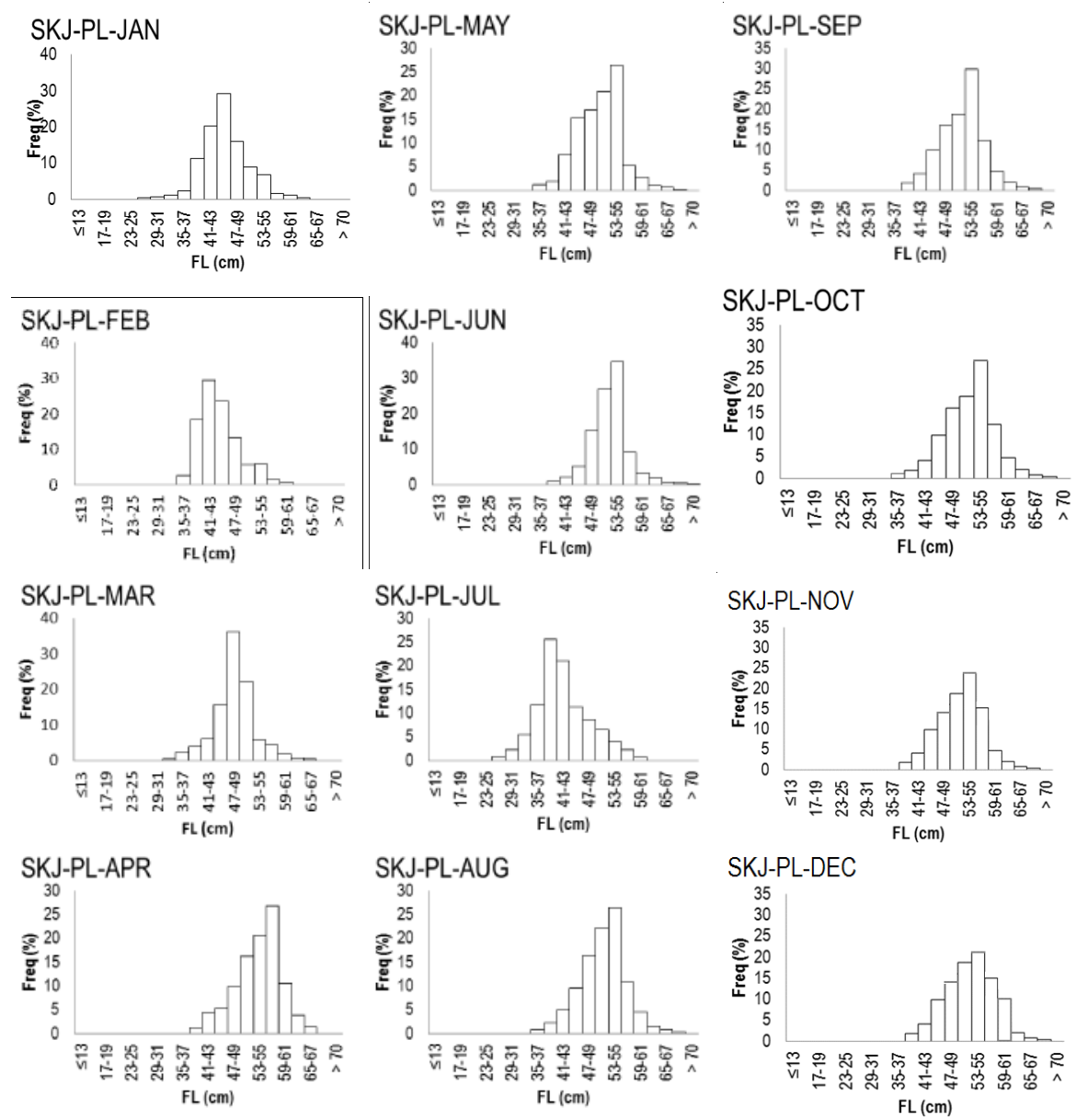

Figure 5. Size distribution of skipjack tuna caught by pole-and-line based at Sorongin 2013.

\section{Discussion}

Capture Fisheries Statistics of Indonesia 2012 (DGCF, 2013) reported that number of unit pole-andliners 7,338 units. That number is alleged excess of the real number and requires clarification. Number poleand-liner reported by Indonesian Pole-and-line and Hand Line Fisheries Association or Asosiasi Perikanan Pole-and-line dan Handline Indonesia (AP2HI) seems more plausible that 134 units in 2014. Decrease the number of pole-and-liners may have occurred, but a decrease of about 7,000 in a year is too much. The decrease of number of pole-and-line is caused some fishers shifted the gear to other gear such as deep hand line in order to catch large tuna such as yellowfin tuna and bigeye tuna to get much higher price. Increasing difficulty in obtaining live bait fish has resulted many pole-and-lines stops fishing. Overlap fishing ground with other fishing gear particularly with purse seine was also resulted decreasing the catch of pole-and-line (Pers. Comm. with Mr. Suyoto operational manager of CRAC Co. Ltd.-Sorong, 2014).
In practical reason mostly pole-and-liners are preferably operated in around fish aggregating devices (FADs) wherefish schoolings are already densely aggregated. Beside pole-and-line, other fishing gears particularly purse seine and troll line/hand line are also using FADs in their fishing. Achieving an estimate of the total number and position of anchored tuna FADs in Indonesia's FMAs 713 - 717 proved difficult. This was largely the result of the current lack of effective systems of FAD registration and monitoring, and also because of the desire of fishing companies and vessel skippers to keep FAD position information confidential.

In term of live-baitfishthree major groups of livebaitfish associate to the Indonesian pole-and-line fisheries i.e. anchovies, sprats and sardine. The efficiency of the use of live-baitfish is indicated by the tuna-live baitfish ratio. The newest information of tunalive baitfish ratio in Western and Central Pacific Ocean (WCPO) was $31.5: 1$ in the period 1977-1980 (Gillett, 2010 in IPNLF, 2012). The tuna-live baitfish ratio in 
Indian Ocean was $7.4-10.0: 1$ (Anderson, 1997in IPNLF, 2012). Tuna-live baitfish ratio in Indonesia was very low i.e. $4.41: 1$. The low of the value of tuna-live baitfish ratio can be affected by several factors such as the baitfish species used, fishing style, and other factors such as lowskill of bait spreader.

The differences of pole-and-line's catch rate for each fishing base (Sorong, Bitungand Kendari) likelyareinfluenced by size of vessel, number of crew (fisher) and number of effective fishing day. Pole-andline vesselwith size61 GT, 25 number of crew and effective fishing day 8 day/trip based at Soronggain inaverage 7.99 tons/trip/vessel. Pole-and-line vesselwith average size 64 GT, 30 number of crew and effective fishing day 10 day/trip based at Bitung has in average catch rate about 12.64 tons/trip/vessel. Pole-and-line vessel with average size 27 GT, 22number of crew and effective fishing day 6 days/ trip based at Kendari has in average catch rate about 4.97 tons/trip/vessel. Suprianto et al. (2012) noted that pole-and-line fleetsbased at Belang, North Sulawesi has in average catch rate 2.04 ton/trip/vessel in 2012. Pole-and-line vessel based at Belang known as funai with average size about 15 GT, number of crew about 8 fishers and effective fishing day about 5 days.

The average catch of pole-and-line in Indonesia during $1980-2013$ was 98,117 tons per year. The amount is approximately $30 \%$ of the total of world's pole-and-line catches which reached an average between 300,000 and 400,000 tonsin the 1970 s to the mid-2000s (Gillett, 2011). In the context of Indonesian tuna fisheries in FMA 713-717, the poleTable 6. The composition (\%) of matured $(\mathrm{FL}>40 \mathrm{~cm})$ and immatured $(\mathrm{FL}<40 \mathrm{~cm})$ of skipjack caught by poleand-line based at Sorong in 2013.

\begin{tabular}{|c|c|c|c|c|c|c|c|c|c|c|c|c|c|}
\hline \multirow{2}{*}{$\mathrm{L}_{\mathrm{m}}$} & \multicolumn{13}{|c|}{$\%$} \\
\hline & Jan & Feb & Mar & Apr & May & Jun & Jul & Aug & Sep & Oct & Nov & Dec & Average \\
\hline$<40 \mathrm{~cm}$ & 15.8 & 20.8 & 6.7 & 12 & 3.1 & 1.0 & 45.8 & 3.1 & 1.7 & 2.9 & 18.8 & 70.2 & 15.9 \\
\hline$>40 \mathrm{~cm}$ & 842 & 79.2 & 93.3 & 98.8 & 96.9 & 99.0 & 542 & 96.9 & 98.3 & 97.1 & 81.2 & 29.8 & 84.1 \\
\hline
\end{tabular}

and-line fishery contributes about $20 \%$ of Indonesia total tuna catch in FMA 713-717 i.e. 480,020 tons as reported to WCPFC in 2014.

The main target of pole-and-line is skipjack with main baycatchjuvenile YFT and BET. Percentage of juvenile yellowfin tuna reached $13.0-16.4 \%$ and juvenile bigeye tuna was $2.9-4.2 \%$ of the total catch. It is possibly caused the pole-and-line fishing in around FADs. The exact reasons for the association of juvenile bigeye tuna and FADs are still not known (Dagorn et al. 2007). But, Castro et al. (2002) stated that FADs provide protection to juvenile bigeye tuna while also providing them with a good food supply, which increases their chances of survival. In addition, drifting objects may help juvenile bigeye and other species migrate to adult habitats. The floating objects are also believed primarily for protection from predators, as a source of food availability and to increase survival of eggs, larvae and juveniles (Gooding \&Magnuson, 1967).Juvenile bigeye may also use FADs as a meeting point to develop larger schools (Fréon and Dagorn 2000). Discriminating juvenile tuna from s

Basedon FL of skipjack caught by pole-and-line based at Sorong in 2013 it indicatesthat the length of first captured $\left(\mathrm{L}_{c}\right)$ ranged from 41 to $55 \mathrm{~cm}$. If the length of first matured $\left(\mathrm{L}_{\mathrm{m}}\right)$ of skipjack is $40 \mathrm{~cm} \mathrm{FL}$ (Naganuma, 1979)so that the size of $L_{c}>L_{m}$., this shows about $84.1 \%$ of the catch inmature condition(Table $6)$. This phenomenon is different from the catch of yellowfin and bigeye that all catch tend to be immatured.

Taking into account that the pole-and-line gear is
mmatured ( $F L<40 \mathrm{~cm}$ ) of skipjack caught by pole- 
selective indicated by more than $80 \%$ of the catch dominated by skipjack. Table 6 show that skipjacks caught by pole-and- line were mostly in matured stage excepted in July and September. Based on that evidence, pole-and-lineis recommended topromote as a gear for Indonesian tuna fisheries. The important improvement which can be meanwhile it should improve the live bait fisheries to support with it operation. It is also required increasing the tuna-live baitfish ratio through better practice of pole-and-line fishery.

\section{CONCLUSION}

The number of pole-and-line fleets has been sharply decreased since 2012 from7,338 units to only 232 units in 2014. The fleetsaremainly based in Sorong, Bitungand Kendari. The national annual total catch of pole-and-line during 1980-2013 is estimated between 24,000 and 160,000 tons per year (in average 98,117 tons per year). The catch contributedabout $20 \%$ of Indonesia annual total catchof tuna caught in Indonesian FMAs 713-717. The pole-and-line catch rates based at Bitung, Kendari andSorong are fluctuated each year ranging between8.79 and 17.93 tons/trip/vessel, 4.78 and 5.36 tons/trip/vesseland about 7,99 tons/trip/vessel, respectively. Skipjack caught by pole-and-line vessels operated in Indonesian FMAs $713-717$ are mostly(more than $80 \%$ of total catch) mature. The tuna-live baitfish ratio4.41: 1for Indonesian pole-and-line wasvery low. Current work found that pole-and-line is a selective gear which was caught skipjackmostly as maturted stage and recommends to promote this gear to be used in developing fishery in Indonesia, especially forlndonesian tuna fisheries, in meantime byimproving the tuna-live baitfish ratio.

\section{ACKNOWLEDGEMENT}

The authors thank to all RCFMC-WCPFC enumerators of port sampling program in Sorong, Bitung and Kendari for providing us data of pole-andline fisheries as well as data of biology aspect the catch.Thanksalso to Mr. Suyoto of Citra Raja Ampat Canning (CRAC) Co. Ltd. for opportunity RCFMC observer to conduct on-board observation program in the pole-and-line vessels under management CRAC Co Ltd. in 2013.

\section{REFERENCES}

Castro, J.J., Santiago, J.A., \& Santana Ortega, A.T. (2002). A general theory on fish aggregation to floating objects: An alternative to the meeting point hypothesis. Reviews in Fish Biology and Fisheries. 11:255-277.

Dagorn, L., Holland, K.N., \& Itano, D.G. (2007). Behavior of yellowfin (Thunnus albacares) and bigeye (T.obesus) in network of fish aggregating devices (FADs). Marine Biology. 151, 595-606.

DGCF. (2013). Capture Fisheries Statistics of Indonesia 2012. Vol. 13. No 1, ISSN 1858-0505. Directorate General of Capture Fisheries, Ministry of Marine Affairs and Fisheries. 240 p.

Fréon, P., \& Dagorn, L. (2000). Review of fish associative behavior: Toward a generalization of the meeting point hypothesis. Reviews in Fish Biology and Fisheries 10:183-207.

Gillett, R. (2010). Replacing purse seining with poleand-line fishing in the Westren Pacific: Some aspects of the baitfish requirements. A report prepared for International Seafood Sustainability Foundation, Washington DC. Gillett, Preston and Associates Inc. 13 p.

Gillett, R. (2011). The promotion of pole-and-line tuna fishing in the Pacific Islands: Emerging issues and lessons learned. ISSF Technical Report 201108. International Seafood Sustainability Foundation, McLean, Virginia, USA. 46 p.

Gillet, R. (2014). Improving the Management of Baitfisheries Associated with Pole-andLine Tuna Fishing in Indonesia. IPNLF Technical Report No. 3, International Pole and Line Foundation, London. $117 \mathrm{p}$.

Gooding, R.M., \& Magnuson, J.J. (1967). Ecological significance of a drifting object to pelagic fishes. Pacific Science 21:486-497.

IPNLF, (2012). Ensuring Sustainability of Live-bait Fish, International Pole-and-line Foundation, London, $57 \mathrm{p}$.

Naganuma, A. (1979). On spawning activity of skipjack tuna in the western Pacific ocean. Bull. Tohoku. Reg. Fish. Res. Lab. 40: 1-13.

Petrere Jr., M., H.C. Giacomini \& Jr. P. De Marco Jr. (2010). Catch-per-unit-effort: which estimator is best?, Braz. J. Biol., 2010, 70 (3), 483-491. 
Stamatopoulos, C. (2002). Sample-based fishery surveys: A technical handbook. FAO Fisheries Technical Paper No. 425. Rome. FAO. 2002. p.132.

Sparre, P., \& Venema S.C. (1998). Introduction to tropical fish stock assessment-Part 1 and 2. FAO
Fish. Tech.Paper No.306/2. Rev.2. FAO, Rome, p. 407.

Suprianto, D., Reppie, E., \& Budiman, J.. (2012). (In Indonesian). The fishing ground of pole and liners based in Coastal Fishery Port Belang. Jurnal IImu dan Teknologi Perikanan Tangkap 1(2),57-62. 